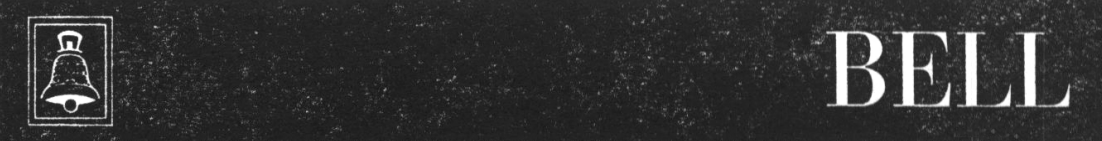

\title{
An Introduction to Basic
}

M. R. EAGLE

Ready immediately. About $\mathbf{\$ 3 . 0 0}$

This book is intended to be an introduction to computer programming using the BASIC language, which was devised specifically so that its logic could readily be mastered.

\section{An Introduction to Algol}

F. R. WATSON

$\$ 2.50$

A clear, brief introduction to the basic ideas of computer programming through the medium of flow charts and the computer language Algol. The book provides a working knowledge of Algol sufficient to enable the reader to write simple programs in that language.

\section{Computer Programming in the Classroom}

\section{B. J. JACKSON}

The volume uses the City and Guilds Mnemonic Code which is widely used in secondary schools and colleges for introductory work. Each chapter contains numerous exercises for the student and the book is illustrated throughout with Flow Charts and Programs.

\section{Multiple Choice Questions on Advanced Level Mathematics}

R. W. PAYNE and D. B. PENNYCUICK

El.95

The questions in this book cover the London G.C.E. A-level syllabus in Mathematics and Further Mathematics to be examined from June 1977. The book should also be of value to students taking A-level of other boards, and to teachers of mathematics in sixth-forms and colleges.

\section{Multiple Integrals}

\section{G. L. COHEN}

A book intended for students of mathematics at tertiary level. The author has attempted to steer around the complexities of the subject and has thus produced a clear, illustrative text suitable for the average student.

\section{Elementary Mechanics}

D. A. QUADLING and A. R. D. RAMSAY

Volume I $\mathbf{2 . 1 5}$ Volume $2 \quad \mathbf{0 2 . 7 5}$

This very successful book has gained a reputation as a first-class text-book of mechanics. The need to introduce SI units has also provided the opportunity for the authors to revise the material in the light of recent changes of thought as to the importance of various topics including greater use of vector methods. 


\section{Participate!}

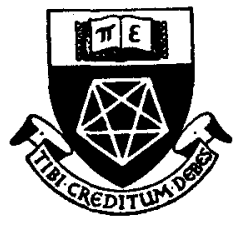

Some of the benefits of membership of the

\section{Mathematical Association:}

- Active local branches

- Annual and 'special interest' conferences

- Access to library of $\mathbf{4 0 0 0}$ mathematical books

- Problems service

- Periodical newsletters

- Regular receipt of Mathematical Gazette and/or Mathematics in School on publication

- Representation on national and local policy-making bodies

- Opportunities to make your own contribution to the improvement of mathematics teaching

Readers of this Gazette who are not already members are invited to write for full particulars to

The Executive Secretary,

The Mathematical Association,

259 London Road

Leicester, LE2 3BE

Special rates for students, members under 25 and members of the Mathematical Association of America. Corporate membership available to schools, colleges and libraries.

\section{You need our support-we value yours}




\section{UNIVERSITY OF KEELE}

\section{STAFFORDSHIRE}

Applications are invited from qualified school teachers and lecturers in Colleges of Education or of Further Education for the following one-year full-time courses which commence in October 1976.

\section{MASTER'S DEGREE COURSE IN MATHEMATICAL EDUCATION}

The course leads to the degree of M.Sc. (Education) and is aimed predominantly at experienced teachers of Mathematics who are concerned with the teaching of Mathematics for the 11-18+ age range. It provides research training and the opportunity for advanced studies of curriculum issues in Mathematics Education. The course components in Mathematics Education are complemented by specialist studies in Mathematics.

\section{DIPLOMA OF ADVANCED STUDY IN EDUCATION - SECONDARY MATHEMATICS}

The Advanced Diploma course is intended to deepen Mathematical knowledge and to examine major aspects of mathematical education in the context of the curriculum as a whole. Written studies arising from practical and experimental work will form part of the assessment of this course which will also include a major study on a topic of the student's choice.

Candidates may also apply to undertake RESEARCH by either full-time or part-time study - towards the degrees of M.A., M.Sc., or Ph.D., in MATHEMATICS EDUCATION OR MATHEMATICS.

Application Forms and further particulars obtained from:

M.Sc., M.A., Ph.D. - The Registrar,

Diploma - The Secretary, The Institute of Education

University of Keele, Keele, Staffordshire. ST5 5BG 

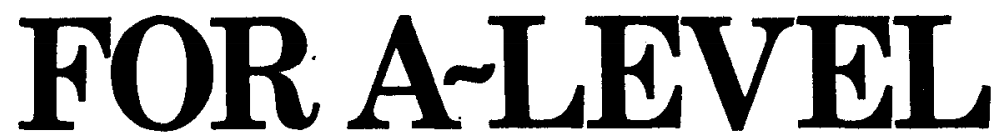

Advanced Mathematics

A Unified Course by $L K$ Turner, $F J$ Budden and $D$ Knighton

A course which covers, with a few minor exceptions, the work of all the new single-subject A-level syllabuses. It combines a direct, clear and unified approach with flexibility in use, since the chapters can be treated as separate sections for teaching purposes. Considerable care has been taken over the selection and arrangement of the exercises at the end of each chapter.

'This well-thought out and well-produced book breaks new ground and can be recommended for students in Sixth Forms and in Further Education preparing for the new, non-traditional syllabuses in A-level mathematics.' - ILEA Contact on Book 1.

Book 1 by $L K$ Turner $£ 2.20 \quad$ Book T by $L K$ Turner $£ 0.75$ Book 2 by $L K$ Turner, $F J$ Budden and $D$ Knighton $£ 3.95$

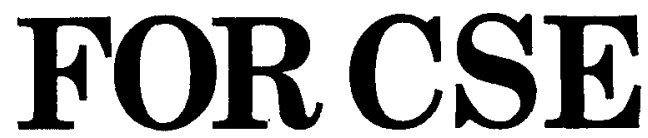

Mathematics at Work Series

Home Mathematics

Third edition A B Tookey $£ 1.20$ (probable)

A book for both CSE and 4th and 5 th year non-examination pupils, which is devoted entirely to the mathematical situations which we all encounter in everyday life. Now completely revised and up-dated for publication in November.

Also available:

\section{Starting Statistics}

$K$ Lewis and $H$ Ward $£ 0.93$

A practical approach to a branch of mathematics which is closely related to real situations. This book has a strongly visual presentation and is designed to encourage pupils to discover facts for themselves.

For publication in March 1976:

\section{Computer Studies}

$B$ Howden and P Reynolds $£ 1.50$ (probable)

For inspection copies, please write to Gill Statham (Ref MG/1), UK School Books Division, Longman Group Limited, Longman House, Burnt Mill, Harlow, Essex CM20 2JE.

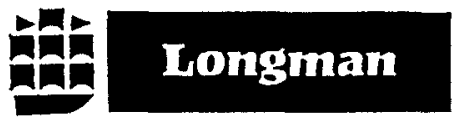




\section{UNIVERSITY OF BIRMINGHAM SCHOOL OF EDUCATION}

\section{DEGREE OF B.PHIL(ED)}

\section{Mathematical Education}

One year full-time course

$$
\text { 1976-7 }
$$

This is a post-experience course intended to meet the needs of all concerned with mathematics teaching in schools and colleges. The major component of the course will be an option in Curriculum and Teaching which will concentrate on Mathematical Education within the context of the school curriculum.

Further details from: W. Curr (Ref. 76J), School of Education, University of Birmingham, P.O. Box 363, Birmingham B15 2TT

\section{Handsome binders \\ for your Gazette}

Covered in dark blue cloth and titled in gold lettering.

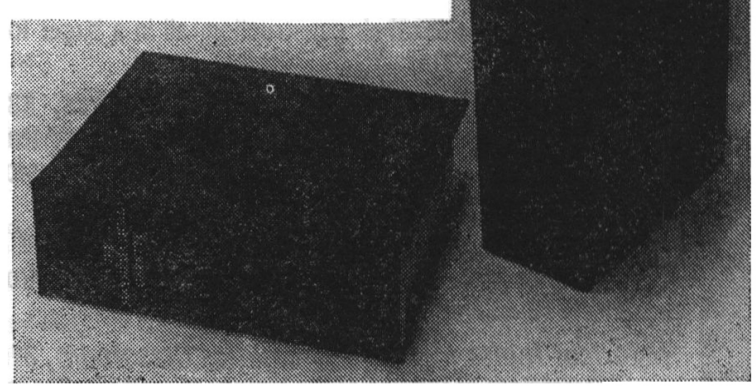

$£ 1$ each including postage, packing \& VAT. Send your order, with remittance, to

The Executive Secretary, The Mathematical Association, 259 London Road, Leicester, LE2 3BE

An extra binder free with each bulk order for 10 binders. 


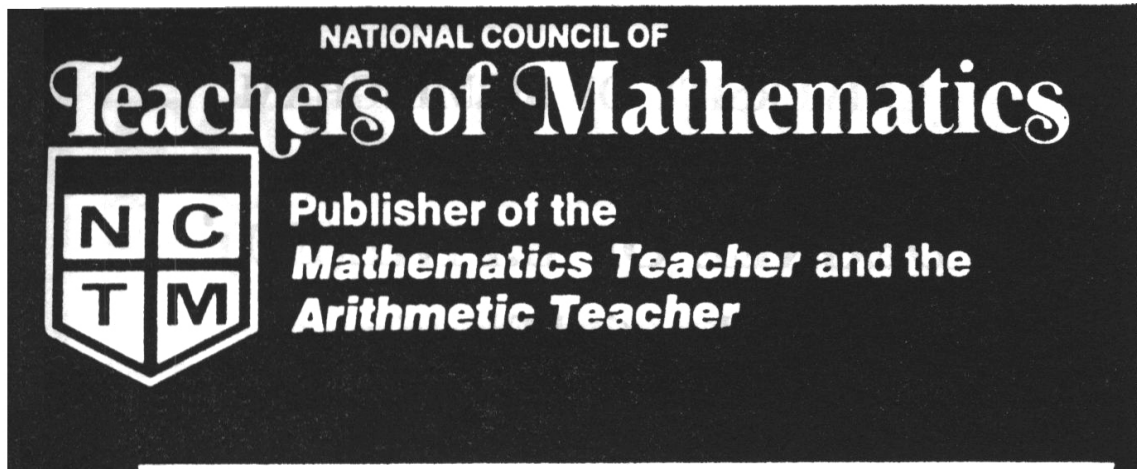

Also publishes a variety of major references on mathematical topics and pedagogical methods concerning mathematics. Here are some of the most recent. (all are clothbound):

Mathematics Leaming in Early Childhood, 37th Yeanook. Colorful. abundantly illustrated resource book for teaching mathematics to children aged 3-8. Chapters on cognition, curriculum, research, and teaching procedures are highlighted by hundreds of ideas and activities in an 81/2-by-11-inch format. 1975, 316 pp., $\$ 13.00^{*}$

Geometry in the Mathematics Curriculum, 36th Yearbook. Presents the various theories on how geometry might best be taught at all levels-informally from kindergarten through the two-year college as well as formally at the secondary level, with illustrations given for each formal approach (conventional, coordinate, transformation, affine, vector). 1973, 480 pp., $\$ 10.00^{*}$

The Slow Learner in Mathematics, 35th Yearbook. Provides ideas for teaching the slow learner at all levels and deals with subject matter objectives while emphasizing methods for attaining them. 1972,528 pp., $\$ 10.60 *$

Instructional Aids in Mathematics, 34th Yearbook. A richly illustrated guide to instructional aids, a basis for evaluating their quality and utility, suggestions for their use, and ideas for their construction, all in a larger format (9-by-11 inches). 1973, 442 pp., $\$ 14.00 *$

The Teaching of Secondary School Mathematics, 33d Yearbook. Forces shaping today's mathematics program are described; teaching for special outcomes is discussed; then examples demonstrate classroom applications, with emphasis on teacher planning. 1970, 433 pp., \$9.50*

A History of Mathematics Education in the United States and Canada, 32d Yearbook. Issues and forces affecting grades K-12 from colonial days to the present. 1970, 557 pp., \$10.60*

Historical Topics for the Mathematics Classroom, 31st Yearbook. A substantial treatment of the use of the history of mathematics in the teaching of mathematics. 1969, 524 pp., \$10.40*

- NCTM members are entitled to a $\$ 2$ discount (one copy only) on each yearbook

All orders totaling $\$ 20$ or less must be accompanied by payment in U. S. currency or equivalent. Make checks payable to the National Council of Teachers of Mathematics. Shipping and handling charges will be added to all billed orders.

NATIONAL COUNCIL OF TEACHERS OF MATHEMATICS 1906 Association Drive, Reston, Virginia 22091 U.S.A. 


\section{A back number?}

We can probably supply it - either individual issues or long runs of the

\section{Mathematical Gazette}

The Executive Secretary will be pleased to send details of availability and prices on request; also a list of Association publications currently available.

The Mathematical Association, 259 London Road, Leicester, LE2 3BE

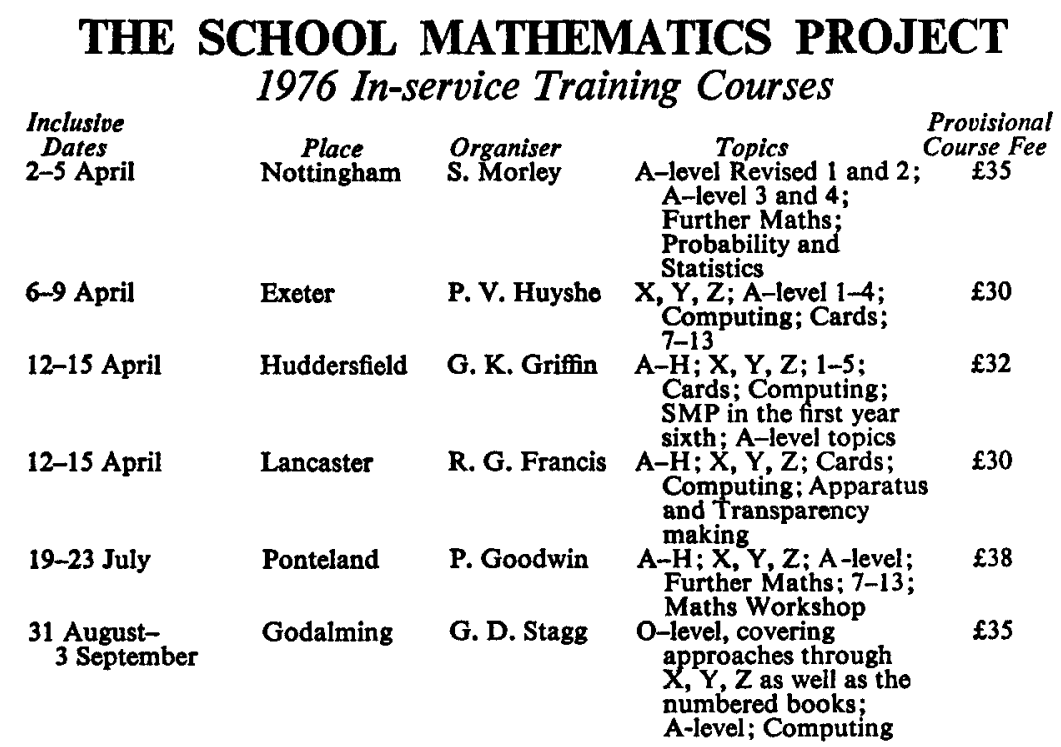

For application forms and further details of any of these courses please write to the SMP Office, Westfield College, Kidderpore Avenue, London NW3 7ST. Please enclose a stamped addressed envelope. 


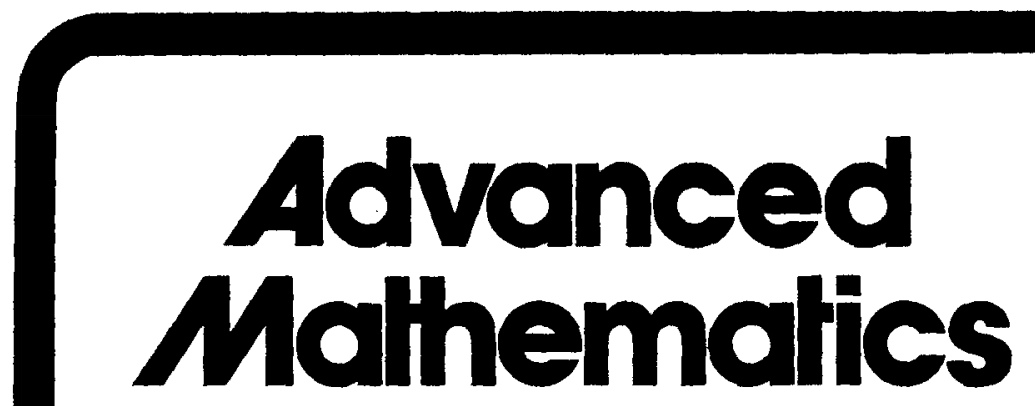

An integrated series of books using modern terminology and notation and written specifically for those ' $A$ ' level and first year university students who have studied modern mathematics.

Taken together, the books cover the whole range of 'Advanced' mathematics at this level.

\section{Algebra and Number Systems Analytic Geometry and Vectors Statistics and Probability} Numerical Analysis Calculus Fortran

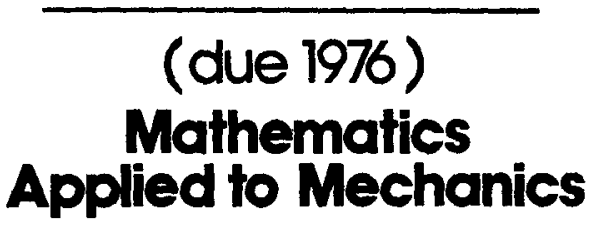

For inspection copies or further. information, write to either publisher.

\section{Blackie}

Bishopbriggs, Glasgow G64 2NZ

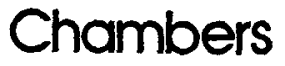

11 Thistle Street, Edinburgh.EH2 1DG 


\section{THE MATHEMATICAL ASSOCIATION}

The fundamental aim of the Mathematical Association is to promote good methods of mathematical teaching. A member receives each issue of the Mathematical Gazette and/or Mathematics in School (according to the class of membership chosen), together with any Newsletters and Reports published during the year. Intending members should ask the Executive Secretary for information and application forms.

The address of the Association and of the Honorary Treasurer and Secretaries is 259 London Road, Leicester LE2 3BE. Telephone (0533) 703877.

Change of address should be notified to the Membership Secretary at the Leicester office. If copies of the Association's periodicals fail to reach a member for lack of such notification, duplicate copies can be supplied only at the published price. If change of address is the result of a change of appointment, the Membership Secretary will be glad to be informed.

Subscriptions should be paid to the Hon. Treasurer.

The Library is housed in the University Library, Leicester.

Correspondence for the Problem Bureau should be addressed to Mr. R. H. Cobb, 9 The Lees, Malvern, Worcs. WR14 3HT.

\section{THE MATHEMATICAL GAZETTE}

\section{Editor:}

Mr. D. A. Quadling, 12 Archway Court, Barton Road, Cambridge CB3 9LW.

\section{Assistant Editors:}

Dr. J. A. Anderson, Department of Mathematics, The University, Nottingham NG7 2RD.

Mr. J. W. Hersee, 76 Pembroke Road, Bristol BS8 3EG.

Material for publication, and books for review, should be sent to $\mathrm{Mr}$. Quadling. Authors will be notified as soon as possible whether or not their contributions can be accepted; if an immediate acknowledgement is required, they should send an addressed, reply-paid postcard with their contribution.

Business and advertising correspondence should be addressed to the Executive Secretary at the Leicester office of the Association. 


\section{CONTENTS}

Mathematics at the university. Universities and Schools Committee 221

Using computers in the teaching of statistics. Peter Holmes 228

Kitchen catastrophe. Michael Sewell 246

How Kepler discovered the elliptical orbit. Eric J. Aiton 250

How to make a portable altitude sun-dial. J. G. Freeman 261

Notes 59.16-24 264

Correspondence $\quad 277$

$\begin{array}{ll}\text { Reviews } & 280\end{array}$ 